\title{
Is autoimmune pancreatitis a risk factor for pancreatic adenocarcinoma?
}

\author{
Lumír Kunovský1, 2,3, Petr Dítě", 4, Martin Blaho4, 5, Jana Dvořáčková5, 6, Magdalena Uvírová ${ }^{5}$, Marie \\ Přecechtělová1, 3, Petr Jabandžiev 3, 7, , Hana Mašková1, 3, Bohuslav Kianička ${ }^{3,9}$, Pavel Janeček 2,3, \\ Michal Eid ${ }^{3,10}$, Arnošt Martínek ${ }^{4,5}$ \\ 'Department of Gastroenterology and Internal Medicine, University Hospital Brno, Brno, Czech Republic \\ ${ }^{2}$ Department of Surgery, University Hospital Brno, Brno, Czech Republic \\ ${ }^{3}$ Faculty of Medicine, Masaryk University, Brno, Czech Republic \\ ${ }^{4}$ Department of Internal Medicine, Department of Gastroenterology, University Hospital Ostrava, Ostrava, Czech \\ Republic
}

${ }^{5}$ Faculty of Medicine, University of Ostrava, Ostrava, Czech Republic

${ }^{6} \mathrm{CGB}$ Laboratory, a. s., Ostrava, Czech Republic

${ }^{7}$ Department of Pediatrics, University Hospital Brno, Brno, Czech Republic

${ }^{8}$ Central European Institute of Technology, Masaryk University, Brno, Czech Republic

${ }^{9} 2^{\text {nd }}$ Department of Internal Medicine, Department of Gastroenterology, St. Anne's University Hospital, Brno,

Czech Republic

${ }^{10}$ Department of Hematology, Oncology and Internal Medicine, University Hospital Brno, Brno, Czech Republic

Immunoglobulin G4-related diseases (IgG4-RD) are a group of diseases characterized by high serum levels of immunoglobulin G4 (lgG4), increased lymphocyte and plasma cell with lgG4 positivity in the parenchyma of some organs, and storiform fibrosis. The most frequently affected organ is the pancreas. This is an autoimmune form of pancreatitis, which can be divided into two types: Type 1, which is significantly more common than Type 2, is high in lgG4 in the pancreatic parenchyma and shows a fundamental difference in the noted presence of extra-pancreatic disorders.

In general, chronic inflammation is a risk factor in the development of carcinomas. Chronic pancreatitis is an accepted risk factor for the development of pancreatic cancer. The question is whether this also applies to autoimmune pancreatitis (AIP), which has some mediators of inflammation in common with sporadic pancreatitis, and what role the presence of IgG4 plays. The vast majority of the work on this topic consists of case reports, yet, even based on our own experience, we would like to say that there is a relationship between the autoimmune form of pancreatitis and pancreatic cancer, which usually occurs in the first two years after diagnosis of AIP. Also significant is the fact that the group of people with AIP, who is a clinical manifestation of IgG4-RD, was found to have an even higher incidence of extrapancreatic cancer than in the pancreas itself. Differentiating AIP from pancreatic cancer can sometimes be problematic since these diseases can both present as focal pancreatic lesions. IgG4 has been considered useful for AIP diagnosis, however, lgG4 levels can be slightly elevated, as in the case with pancreatic adenocarcinoma. IgG4 levels of over twice the upper limit are rare among patients with pancreatic adenocarcinoma. However, cases of simultaneous presentation of pancreatic cancer and AIP have been documented and should not be neglected.

AIP is a condition where regular follow-up is mandatory, including from the perspective of possible cancerogenesis.

Key words: chronic inflammation, carcinogenesis, autoimmune pancreatitis, chronic pancreatitis, pancreatic adenocarcinoma, immunoglobulin G4. 


\section{Je autoimunitní pankreatitida rizikovým faktorem adenokarcinomu pankreatu?}

Imunoglubulin G4 asociované nemoci tvoří skupinu chorob, které charakterizuje vysoká hladina imunoglobulinu G4 (IgG4) v krevním séru, zvýšený obsah lymfocytů a plasmatických buněk s lgG4 v parenchymu některých orgánů a storiformní fibróza. Nejčastěji postiženým orgánem je pankreas. Hovoříme o autoimunitní formě pankreatitidy, která se rozlišuje na dva typy. 1. typ s vysokým obsahem lgG4 v pankreatickém parenchymu je významně častěǰ̌í než 2. typ a má zásadní odlišnost, i pokud jde o prítomnost extrapankreatických postižení.

V obecné rovině platí, že chronický zánět patří mezi rizikové faktory vzniku karcinomu. Chronická pankreatitida je tak akceptovaným rizikovým faktorem vzniku pankreatického karcinomu. Je otázkou, zda toto platí i o autoimunitní pankreatitidě (AIP), která má některé mediátory zánětu shodné s pankreatitidou sporadickou, a jakou roli hraje př́tomnost imunoglobulinu G4. Naprostá většina prací s touto tematikou jsou kazuistická sdělení, přesto však, a to i na základě vlastních zkušeností, si dovolujeme tvrdit, že existuje vztah mezi autoimunitní formou pankreatitidy a pankreatickým karcinomem, který se objevuje obvykle v prvních dvou letech od stanovení diagnózy AIP. Významný je rovněž fakt, že u skupiny osob s AIP, která je klinickou manifestací lgG4 asociovaných onemocnění, byl nalezen dokonce vyšší výskyt nádorových onemocnění extrapankreatických, než tomu bylo v pankreatu samotném.

Diferenciální diagnostika AIP od karcinomu pankreatu může být někdy problematická, protože tato onemocnění se mohou projevovat obě jako fokální pankreatické léze. IgG4 je považován za užitečný pro diagnostiku AIP, avšak hladiny lgG4 mohou být mírně zvýšené i v prípadě adenokarcinomu pankreatu. Hladiny lgG4 přesahující dvojnásobek horní hranice jsou u pacientů s adenokarcinomem pankreatu vzácné. Byly však zdokumentovány př́pady současného projevu karcinomu pankreatu a AIP, a proto ani tato možnost by neměla být opomíjena.

AIP patří mezi stav, jenž vyžaduje pravidelnou dispenzarizaci, a to i z pohledu možné kancerogeneze.

Klíčová slova: chronický zánět, kancerogeneze, autoimunitní pankreatitida, chronická pankreatitida, adenokarcinom pankreatu, immunoglobulin G4.

\section{Introduction}

IgG4-related disease (lgG4-RD) can be linked with many organs, such as the biliary tract, liver, salivary gland and lacrimal glands, kidney, prostate, lungs, breast, thyroid, pericardium, lymph nodes and skin $(1,2)$.

Cancer tissue can also be infiltrated by lgG4 plasma cells, however this infiltration is usually with variable density and counts of IgG4 plasma cells. There is no association with typical lgG4-RD histological markers. This fact poses the question, if synchronous carcinoma and lgG4-RD represent a true association or a non-specific pericancerous lgG4 reaction; this remains unresolved (3).

The autoimmune form of chronic pancreatitis is a relatively rare disease characterized initially by the presence of an obstructive icterus, lymphoplasmatic infiltration, storiform pancreatic parenchyma fibrosis with intraparenchymatous venulitis, and further an abundant presence of immunoglobulin G4 (lgG4) in serum, with an increase in IgG4-positive plasma cells in the parenchyma. A typical feature is a favourable response to steroid therapy (4), which is reported as one of the diagnostic criteria. In the pathogenesis of autoimmune pancreatitis (AIP), the multifactoriality of the process is a characteristic feature to which autoimmunity, genetic and environmental factors contribute. As noted, the autoimmune form of pancreatitis is the clinical manifestation of a set of diseases referred to as lgG4-RD. These diseases are characterized by a high presence of plasma cells and positivity of lgG4 not only in blood serum, but also in cells of parenchymatous tissues. In addition, the disease is closely associated with an increase in interferon-1 (INF-1), which is produced by plasmacytoid dendritic cells. Increased INF-1 production is one factor in the pathogenesis of AIP (5). In addition to the autoimmune form of pancreatitis, INF-1 (usually alpha) is known to be an important factor in the development of other autoimmune diseases, such as in those with systemic lupus erythematosus (SLE) (6). Attention in the pathogenesis of AIP is also given to genetic and immunological factors (7). Interesting results have been reported by a Japanese study, which described as a possible new genetic factor HLA serotype DRB1 0405 and DRB1 0401 (8). However, this undoubtedly interesting result has not yet been confirmed by further studies. People with AIP demonstrate a high level of antibodies. Positive antinuclear antibodies were found in 40\% of patients, antibodies against anhydrase II and PSTI (pancreatic secretory trypsin inhibitor) in 55\% and against lactoferrin in as many as 75\% (9). Environmental factors include the long-term action of certain substances, such as mineral oils and certain polymers.

\section{The classification of autoimmune pancreatitis}

In 2012, recommendations were published regarding the nomenclature of AIP (10). There are thus two types of AIP. Type 1, also referred to as lymphoplasmatic sclerosing pancreatitis (LPSP), is reported to be an autoimmune form which is a manifestation of IgG4 associated pancreatitis. Type 2 is not associated with IgG4$\mathrm{RD}$ and is designated as idiopathic duct centric pancreatitis (IDCP) (11). Key characteristics and differences between type 1 and type 2 autoimmune forms of pancreatitis are shown in Table 1 (adapted according to Webster (11)).

\section{Autoimmune pancreatitis and pancreatic cancer}

An important issue is the existence of a relationship between the autoimmune form of pancreatitis and pancreatic cancer, similar to that of patients with chronic pancreatitis (12). In a study by Malka et al. 
(13) in patients with chronic pancreatitis (predominantly of alcoholic origin) they report pancreatic cancer in 1.1\% of, in total, 3437 patients with chronic pancreatitis.

AIP is still a rare disease, so most of the work on it is in the category of case reports. Studies with higher numbers of test subjects show somewhat different results. In a study evaluating a group of 68 patients with AIP at 75-month intervals, no cancer was found (14). A multicentric study from the Mayo Clinic (15), including 23 departments from 10 countries, and a total of 1064 patients with AIP, did not show a significant increased risk of malignancies ( 57 malignancies and of those only 5 cases of pancreatic cancer, 0.8\%). However, Ikeura et al. (16) in a single-centre trial showed a trend towards higher pancreatic cancer development in patients with AIP (4.8\%) against patients with other chronic pancreatites (2.4\%). Ikeura et al. (17), also in his review article, summarizes the incidence risk of pancreatic cancer in AIP patients at between $0 \%$ and $4.8 \%$. Pancreatic cancer occurs in the vast majority of people with type 1 AIP $(8,18)$.

AIP is a clinical manifestation of a group of diseases called lgG4-RD. In this context, the question arose whether IgG4-RD were associated with the induction of the process of carcinogenesis. Shiokawa et al. in a retrospective study of 108 subjects with AIP, found malignancy present in 13.9\% (19), with a standardized incidence rate of 2.7. In the study of Asano et al. of 109 subjects with AIP, cancer was found in $26 \%$ of cases (20). However, only 4 cases were of pancreatic cancer. These results indicate that IgG4-RD can be a risk factor for cancer in various organ localities. Also in a study from Hirano et al. (21), which evaluated a set of 113 patients with lgG4-RD, a malignancy was diagnosed at the time of IgG4-RD onset in 15 cases. Most frequently this was lung cancer, with pancreatic cancer detected only in two cases. Interestingly, in patients with AIP, cancer is diagnosed mostly in the years immediately after or soon after the diagnosis of autoimmune disease.

Macinga et al. (22) in a retrospective study assess the occurrence of AIP in pancreatic masses resected for a focal pancreatic enlargement. In 295 pancreatic resections, AIP was diagnosed in 15 patients (5.1\%). Six of them had AIP type 1, nine were diagnosed as AIP type 2. In the group of patients with AIP pancreatic adenocarcinoma were diagnosed in 6 cases (40\%). An important fact here is that AIP was not diagnosed before surgery.

It's in no doubt that focal pancreatic enlargement, low density on $C T$, female gender, and rim enhancement on MRI in patients with AIP type 1 are suggestive of pancreatic cancer in these patients (18).

The incidence of malignances in patients with AIP is described by Schneider et al (23). It's important that the incidence of malignancy in patients with AIP, versus regular population is higher by $17.9 \%$.

In our study, published by Bojkova et al. (12), we examined the presence of the serum IgG4 in 106 patients with histologically documented pancreatic cancer, without any previous diagnose of AIP. Higher serum lgG4 over the normal level of $135 \mathrm{mg} / \mathrm{dL}$ was found in 11 patients. Of these 11 patients, 7 (65.6\%) had a level twice higher than the limit of $135 \mathrm{mg} / \mathrm{dL}$. The average lgG4 value in the pancreatic carcinoma group was $263 \mathrm{mg} / \mathrm{dL}$. Pancreatic tissue biopsy material was obtained from all subjects and pancreatic adenocarcinoma was detected simultaneously in 2 subjects with a diagnosis of AIP.

In summary, lgG4 has been considered useful for AIP diagnosis, however, lgG4 levels can be slightly elevated also in patients with pancreatic adenocarcinoma. IgG4 levels of over twice the upper limit are rare among patients with pancreatic adenocarcinoma. However, cases of simultaneous presentation of pancreatic cancer and AIP have been documented and should not be neglected.

\section{The role of NF-kappaB}

Despite a number of new findings in recent years, the mechanisms of the relationship of chronic inflammation and the induction of tumor growth are still not entirely clear (24). However, what is unequivocally accepted is the relationship between chronic inflammation, nuclear factor-kappaB (NF-kappaB) activation and tumor growth (25). The role of NF-kappaB in the process of inflammation and inflammation associated with tumor growth is shown in Figure 1 (edited according to (24) - created in collaboration with Service Center for E-Learning at Masaryk University, Faculty of Informatics).

NF-kappaB is a factor that regulates pro-inflammatory processes. Activation of NF-kappaB involves translocation of active dimers into the cell

Tab. 1. Characteristics and essential differences between Type-1 and Type-2 autoimmune pancreatitis (adapted according to Webster [11])

\begin{tabular}{|l|c|c|}
\hline & TYPE-1 & TYPE-2 \\
\hline IgG4 - RD & Yes & USA/Europe $>$ Asia \\
\hline Prevalence & Asia > USA/Europe & Male = Female \\
\hline Gender & Male > Female & $<10$ \\
\hline AIP in the world in \% & $>90$ & $<0-50$ \\
\hline Predominant age & $>50$ & $>30$ \\
\hline Initial jaundice & $>60$ & $<60$ \\
\hline Acute abdomen pain & $<30$ & IDCP \\
\hline Increased IgG4 in serum & $>70$ & GEL \\
\hline Histopathology & IgG4-LPSP \\
& Storiform fibrosis \\
\hline Other organ disabilities & Obliterative phlebitis & No \\
\hline Presence of IBD in $\%$ & Yes & $>40$ \\
\hline Response to steroids & $<10$ & $>90$ \\
\hline Relapse after steroid therapy & $>90$ & $<10$ \\
\hline
\end{tabular}

IgG4-RD - IgG4-related disease, LPSP - lymphoplasmatic sclerosing pancreatitis, IDCP - idiopathic duct centric pancreatitis, GEL - granulocytic epithelial lesions, IBD - Inflammatory bowel disease 
Fig. 1. The role of NF-kappaB in the inflammatory process and in the case of inflammation associated with carcinoma (modified according to Zhang et al. (24) - created in collaboration with Service Center for E-Learning at Masaryk University, Faculty of Informatics). A - Leukocytes and stromal cells secrete an abundance of proinflammatory proteins during inflammation. B - Proinflammatory factors in the microenvironment of latent pre-malignant cells lead to the accumulation of DNA damage, which, in turn, causes these cells to become malignant. C - Activation of NF-kappaB in pre-malignant cells induces anti-apoptotic signals, which prevents apoptosis and enhances their proliferation. D and E-Leukocytes and stromal cells secret proinflammatory proteins in their chronically inflamed microenvironment, which stimulates tumor progression and metastasis

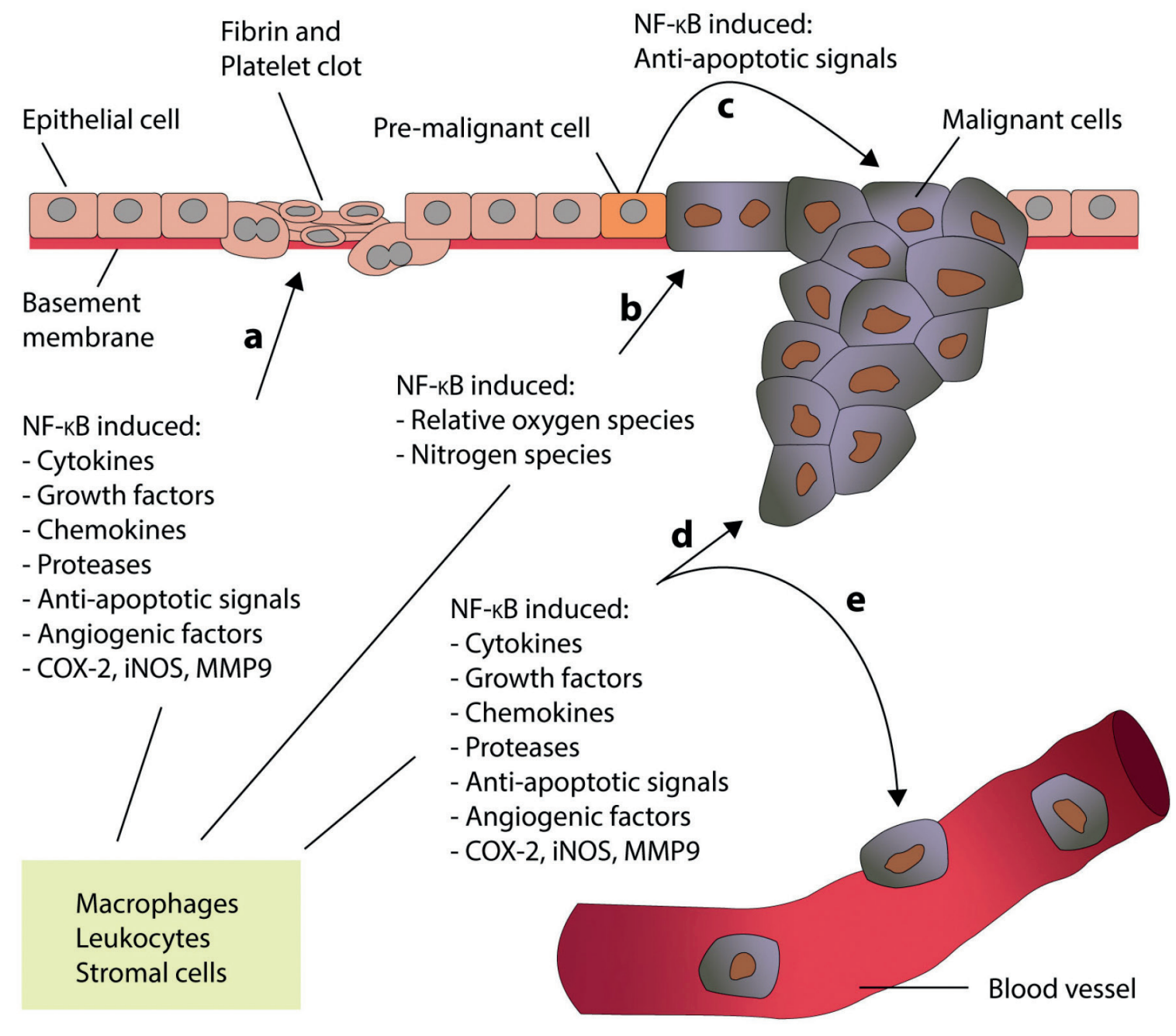

nucleus, which in turn activates transcription of pro-inflammatory cytokines, adhesion molecules, chemokines, growth factors, anti-apoptotic genes, and cyclin D1 (26,27). It should be noted that NF-kappaB induces the production of other proteins, such as COX-2 and nitric oxide synthetase. Thus, it can be deduced that NK-kappaB forms the molecular link between the activation of inflammation and the simultaneous loss of the physiological cell cycle in carcinomas, which is referred to as a dualistic effect.

The three findings that indicate that NF-kappaB is an essential factor in pancreatic cancer are:

- 1) NF-kappaB is activated in $70 \%$ of pancreatic cancers and in human pancreatic cell lines such as PANC-1 and BxPC-3 $(28,29)$.

- 2) Supporting arguments from experimental studies - e.g. suppression of NF-kappaB leads to re-initiation of apoptosis in pancreatic tumor cells (30).

- 3) NF-kappaB appears to be involved in the early stages of pancreatic carcinogenesis, which is related to its relationship to the K-ras oncogene and apoptotic resistance (31).
K-ras mutations play a prominent role in the induction of pancreatic carcinogenesis. In 2009, Kamisawa et al. published a paper demonstrating high positive rates of K-ras mutation in pancreatic tissue of individuals with AIP (32). He found positive rates in the tissue of all persons examined with an autoimmune form of pancreatitis. However, K-ras mutation can be detected in $90 \%$ of cases of sporadic pancreatic cancer (33).

\section{Conclusion}

AIP, like sporadic chronic pancreatitis, is a risk factor for pancreatic cancer. Chronic inflammation is a precursor of tumor growth. Whereas in the case of chronic pancreatitis, the inflammation-tumor sequence is only connected with pancreatic tissue, in the form of chronic AIP, which is one of the clinical manifestations of a group of diseases referred to as IgG4-RD, malignancy may occur in an organ other than the pancreas. It seems that the appearance of such cancers occurs soon after the diagnosis of AIP. 
It is therefore necessary to include in our armamentarium of screening programmes the screening of patients with AIP with a view to the possible induction of more than only pancreatic cancer.
Grants or financial support:

Supported by Ministry of Health, Czech Republic - conceptual development of research organization (FNBr, 65269705).

\section{REFERENCES}

1. Stone JH, Zen J, Desphande V. Mechanisms of disease. IgG4- related disease. N Engl J Med 2012; 366(6): 539-551.

2. Miyabe K, Zen Y, Cornell LD, et al. Gastrointestinal and Extra-Intestinal Manifestations of IgG4-Related Disease. Gastroenterology. 2018; 155(4): 990-1003.e1.

3. Desphande V, Zen Y, Chan JKC et al. Consensus statement on the pathology of IgG4-related disease. Modern Pathol 2012; 25: 1181-1192.

4. Shimosegawa T, Chari ST, Frulloni L et al. International consensus diagnostic criteria for autoimmune pancreatitis, guidelines of the International Association of Pancreatology. Pancreas 2011; 40: 352-358.

5. Paras A. Type I interferon - mediated autoimmune disease: pathogenesis, diagnosis and target therapy. Rheumatology 2017; 66: 1662-1675.

6. Watanabe T, Minaga K, Kamata K. Mechanistic insights into autoimmune pancreatitis Trends in Immunology 2018; 39(1): 874-889.

7. Hart PA, Zen Y, Chari ST. Recent advances in autoimmune pancreatitis. Gastroenterology 2015; 149: 39-51.

8. Kawa S, Ota M, Yoshizawa Ket al. HLA DRB10405 - DQB10401 haplotype is associated with autoimmune pancreatitis in Japanese population. Gastroenterology 2012; 122: 1264-1269. 9. Okazaki K, Uchida K, Fukui T et al. Recent advances in autoimmune pancreatitis. Gastroenterol Hepatol (N Y). 2008; 4(6): 417-426.

10. Stone JH, Klosroshah A, Desphande V et al. IgG4-Related Disease: Recommendations for the Nomenclature of this Condition and its Individual Organ System Manifestations. Arthritis Rheum 2012; 64: 532-539.

11. Webster GJ. Autoimmune pancreatitis - a riddle wrapped in an enigma. Dig Dis 2016; 34: 532-539.

12. Bojkova M, Dite P, Dvorackova J et al. Immunoglobulin G4, autoimmune pancreatitis and pancreatic cancer. Digestive Disease 2015; 33(1): 86-90.

13. Malka D, Hammel P, Maire F et al. Risk of pancreatic adenocarcinoma in chronic pancreatitis. Gut. 2002; 51(6): 849-852. DOI: 10.1136/gut.51. 6. 849.

14. Buijs J, Cahen DL, van Heerde MJ et al. The long-term impact of autoimmune pancreatitis on pancreatic function. Quality of life and life expectancy. Pancreas 2015; 44(7): 1065-1071. 15. Hart PA, Kamisawa T, Brugge WR, et al. Long-term outcomes of autoimmune pancreatitis: a multicentre, international analysis. Gut. 2013; 62(12): 1771-1776.

16. Ikeura T, Miyoshi H, Uchida K, et al. Relationship between autoimmune pancreatitis and pancreatic cancer: a single-center experience. Pancreatology. 2014 Sep-Oct;14(5): 373-379. 17. Ikeura T, Miyoshi H, Shimatani M, et al. Long-term outcomes of autoimmune pancreatitis. World J Gastroenterol. 2016; 22(34): 7760-7766. doi:10.3748/wjg.v22.i34.7760
18. Xiang $P$, Zhang $X$, Lang $Y$ et al. Pancreatic tumour in type 1 autoimmune pancreatitis: a diagnostic challenge. BMC Cancer 2019; 19: 814. doi.org/10.1186/s12885-O19-6O27-O 19. Shiokawa M, Kodama Y, Yoshimura K et al. Risk of cancer in patients with autoimmune pancreatitis. Am J Gastroenterol 2013; 108(4): 610-617.

20. Asano J, Watanabe T, Oguchi T et al. Association between immunoglobulin G4-related disease and malignancy within 12 years after diagnosis: An analysis after longterm followup. J Rheumatol 2015; 42(11): 2135-2142.

21. Hirano K.,Tada M., Sasahira N et al : Incidence of malgnancies in patients with IgG4-related disease- Iternal Med 2014, 53: 171-176.

22. Macinga P, Pulkertova A, Bajer L et al. Simultaneous occurrence of autoimmune pancreatitis and pancreatic cancer in patients resected for focal pancreatic mass. WJG 2017; 23(12): 2185-2193.

23. Schneider A, Hirth M, Munch M et al. Risk of cancer in patients with autoimmune pancreatitis.: A singe center experiences from Germany. Digestion 2017; 95: 172-180.

24. Zhang Z, Rigas B. NF-kappaB, inflammation and pancreatic carcinogenesis: NF-kappaB as a chemoprevention target (review). Int J Oncology 2006; 29: 185-192.

25. Fujioka S, Sclabas GM, Schmidt C et al. Inhibition of constitutive NF-kappaB activity by I kappa B alpha M supresses tumorigenesis. Oncogene 2003; 22: 1365-1370.

26. Garcea G, Neal CP, Pattenden CJ et al. Molecular prognostic markers in pancreatic cancer: a systematic review. Eur J Cancer 2005; 41: 2213-2236.

27. Bonizzi G, Karin M. The two NF-kappaB activation pathways and their role in innate and adaptive immunity. Trends Immunol 2004; 25: 280-288.

28. Sclaba GM, Uwagawa T, Shmidt C et al. Nuclear factor kappa B activation is a potential target for preventing pancreatic carcinoma by aspirin. Cancer 2005; 103: 2485-2490. 29. Chandler NM, Canete JJ, Callery MP. Increased expression of NF-kappa B in human pancreatic cancer cells. J Surg Res 2004; 118: 9-14.

30. Sclaba GM, Fujoka S, Schmidr C et al. Restoring apoptosis in pancreatic cancer cells by targeting the nuclear factor kappaB signaling pathway with the anti-epidermal growth factor antibody IMC-C 225. J Gastroint Surgery 2003; 7: 37-43

31. Liptay S, Weber CK, Ludwig L. et al. Mitogenic and anti-apoptotic role of constitutive NF-kappaB/Rel activity in pancreatic cancer. Int J Cancer 2003; 105: 735-746.

32. Kamisawa T, Tsuruta K, Okamoto A et al. Frequent and significant K-ras mutation in the pancreas, the bile duct and the gallbladder in autoimmune pancreatitis. Pancreas 2009; 38(8): 890-895.

33. Fan Z, Fan K, Yang C, et al. Critical role of KRAS mutation in pancreatic ductal adenocarcinoma. Transl Cancer Res 2018; 7(6): 1728-1736.

\section{KNIŽNII NOVINKY}

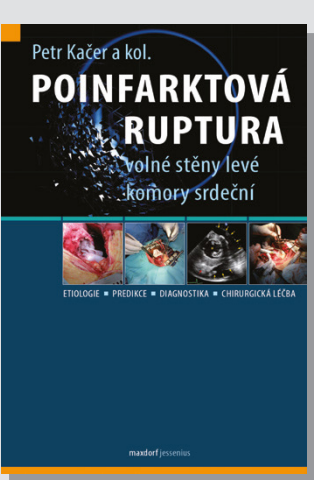

\section{POINFARKTOVÁ RUPTURA VOLNÉ STĚNY LEVÉ KOMORY SRDEČNÍ}

Petr Kačer a kol.

Ruptura volné stěny levé komory je obávanou a katastrofickou komplikací akutního infarktu myokardu zatiženou vysokou mortalitou. Ta se ještě donedávna bližila 100 \% a šance na přežití byla mizivá. Dynamický rozvoj kardiochirurgie a diagnostických metod v posledních dekádách však prognózu této dřive fatální diagnózy začal měnit: ruptura nevzniká náhle, její vývoj vyžaduje určitý čas, ve kterém je možné nemocného zachránit.

Pokud kardiolog u nemocného na možnost vzniku ruptury myslí a cíleně sleduje klinické, echokardiografické a jiné prediktory naznačujicí možný vznik a rozvoj ruptury, dává pacientovi šanci na život zachraňující kardiochirurgický zákrok.

Kniha obsahuje velké množství jedinečného fotografického materiálu demonstrujicího chirurgické techniky i intraoperační a echokardiografické nálezy. Instruktivní kazuistiky ukazuji, že včasné stanovení diagnózy a kardiochirurgická operace může nemocnému zachránit život a vrátit jej k plnohodnotnému životu, jako je to dnes běžné u většiny nemocných po infarktu.

Kniha je určena především kardiologům, kardiochirurgům, anesteziologům a intenzivistům. Věříme, že se stane užitečným nástrojem pro všechny, kdo pečují o pacienty po infarktu. Jedním z jejích cílů je změnit vnímání poinfarktové ruptury mezi lékaři a zásadně zvýšit počet těch pacientů, které se podaři zachránit.

Maxdorf 2020, 232 str., barevné ilustrace, edice Jessenius, ISBN 978-80-7345-646-7, Cena: 595 Kč, Formát:154×230 mm, pevná

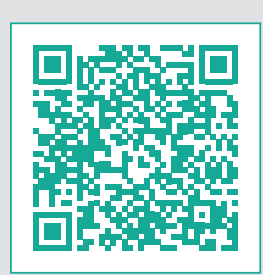

